\title{
Effects of Calcium Treatment on Physical and Biochemical Changes of Cold-Stored Sweet Cherry Fruit
}

\section{Derya ERBAŞ ${ }^{1}$ (D), Mehmet Ali KOYUNCU1 ${ }^{\circledR}$}

${ }^{1}$ Isparta University of Applied Science Agriculture Faculty Horticulture Department, 32000, Isparta / Turkey

\author{
Article History \\ Received 15 October 2020 \\ Accepted 20 November 2020 \\ First Online 16 December 2020
}

\section{Corresponding Author \\ E-mail: deryaerbas@isparta.edu.tr}

\author{
Keywords \\ Bioactive compounds \\ Calcium gluconate \\ Prunus avium \\ Stem chlorophyll content
}

\begin{abstract}
In the present study, sweet cherry fruit (Prunus avium cv. 0900 Ziraat) were dipped into calcium (Ca) gluconate (calcium concentration of $1.5 \%$ ) and distilled water (as control). The treated fruit were stored at $1 \pm 0.5^{\circ} \mathrm{C}$ and $90 \%$ relative humidity for 4 weeks in two different packages. At weekly intervals, weight loss, fruit firmness, colour changes, soluble solids content, titratable acidity, sensory analysis, total phenolic and anthocyanin content of fruit and total chlorophyll content of stem were evaluated. As a result, $\mathrm{Ca}$ treatment positively affected sweet cherry fruits by maintaining firmness and decreasing respiration rate of sweet cherry fruit. Moreover, $\mathrm{Ca}$ treatment generally delayed the skin browning, and maintained fruit quality. Stem chlorophyll decomposition was retarded with $\mathrm{Ca}$ throughout cold the storage. Considering the sensory analysis, storage life of fruit could be prolonged at least up to 1 week by $\mathrm{Ca} 1$ (treated $\mathrm{Ca}-\mathrm{Glu}$ and stored in plastic box with lid) treatment compared to other treatments.
\end{abstract}

\section{Introduction}

Sweet cherry is one of the most attractive fruit for consumer in the world because of its own taste and aroma. Cherries are rich in nutrients such as vitamins ( $\mathrm{C}, \mathrm{A}$ and $\mathrm{K}$ ), minerals (potassium, magnesium etc.). Additionally, sweet cherry fruit contains bioactive compounds (polyphenols, anthocyanins etc.) which have positive effects on health. Increasing the consumption of sweet cherry is associated with these compounds (Le Nguyen et al., 2020). Sweet cherry fruit is generally consumed as fresh therefore, the quality parameters that affect consumers are mostly important. The main quality criterias widely used sweet cherry fruit are firmness, fruit skin and stem colour, acidity and sugar content (Göksel and Aksoy, 2014). Especially sweetness, firmness and colour of sweet cherry fruit influence consumers' acceptance (Göksel et al., 2013). Because of the high respiration rate, harvested sweet cherry fruit are susceptible to handling, storage, transportation and marketing. The main causes of quality losses during cold storage are water loss, softening, colour deterioration, stem browning, pitting and fungal decays (MartínezRomero et al., 2006). Therefore, postharvest treatments and appropriate storage conditions to maintain postharvest quality are very important for sweet cherry fruit (Miranda et al., 2020).

Pre/postharvest treatments of calcium ( $\mathrm{Ca}$ ) play an important role to increase storability and promote postharvest quality of cherries. After harvest, $\mathrm{Ca}$ dipping and vacuum infiltrations treatments are one of the most used techniques to increase the calcium content of cell wall. Ca affects the cell wall structure, membrane integrity and cell wall strength in fruit (Dong et al., 2019). In addition, it is reported that $\mathrm{Ca}$ applications can reduce decay rate and disorders during storage (Wang et al., 2014; Michailidis et al., 2017). Exogenous Ca treatments and the positive 
effects of it on the fruit quality during cold storage have been stated in many studies (Wójcik and Wawrzyńczak, 2014; Michailidis et al., 2017; Hosein-Beigi et al., 2019; Öztürk et al., 2019). But these reported effects on the quality may vary depending on the source of $\mathrm{Ca}$, treatment timing, concentration, environmental conditions and cultivars. Although $\mathrm{Ca}$ treatments have positive effects on fruit quality, it has been stated that sometimes inorganic salts like calcium chloride $\left(\mathrm{CaCl}_{2}\right)$ change the fruit taste-aroma (MonsalveGonález et al., 1993). But using the organic salts such as calcium gluconate (Ca-Glu), lactate and citrate can suppresses the undesirable taste-aroma (Hernández-Muñoz et al., 2006).

Previous studies have shown that the storage temperature and techniques such as modified atmosphere, controlled atmosphere and dynamic controlled atmosphere are effective in prolonging the postharvest life of stone fruit by delaying quality losses. With these informations in this study, the effects of Calcium glucanate on physical and biochemical changes of 0900 Ziraat sweet cherry fruit during during storage were investigated.

\section{Material and Methods}

\subsection{Material}

Sweet cherry (Prunus avium cv. 0900 Ziraat), which have standard size and colour, were handharvested (16 June 2020) at commercial maturity stage in Isparta-Turkey. Cherry trees were 8 years old and grafted on Prunus mahaleb L. rootstocks. Immediately after harvest, fruit were transfered to the laboratory within one hour, and undesireable parts and injured fruit were removed. After visual examination, fruit were divided into two lots. Fruit were dipped into a $4^{\circ} \mathrm{C}$ Ca-Glu solution (calcium concentration of $1.5 \%$ ) for 30 sec or control (distilled water). Tween $20(0.1 \%)$ was added to all solutions (including control) as the spreading adhesive. The doses and dipping time of Ca-Glu (Califast, Crops MCS) was chosen according to Akhtar and Rab (2014). Following each treatment, sweet cherry fruit were air-dried for $30 \mathrm{~min}$ at room conditions then fruit $(750 \mathrm{~g})$ were placed into plastic boxes $(18 \mathrm{~cm} \times 11 \mathrm{~cm} \times 7.5 \mathrm{~cm})$. After treatments control and $\mathrm{Ca}-$-Glu treated fruits were placed into plastic boxes with lid or without lid. Plastic boxes with lid $(1 \mathrm{~kg})$ have 8 perforation holes with $5 \mathrm{~mm}$ diameter. As a result, the study was arranged as 4 different treatments; Control group in plastic box with lid (C1), control group in plastic box without lid (C2), $\mathrm{Ca}-\mathrm{Glu}$ in plastic box with lid (Ca1) and Ca-Glu in plastic box without lid ( $\mathrm{Ca} 2$ ). All boxes were stored at $1 \pm 0.5^{\circ} \mathrm{C}$ and $90 \%$ relative humidity $(\mathrm{RH})$ for 4 weeks, and fruit samples were analyzed at weekly intervals. Each box represented a replication.

\subsection{Physical and chemical analysis}

Weight loss: The boxes of cherry fruit were weighed initially and recorded. At each analysis day, the same boxes were weighed, and weight loss was determined by the difference between the initial and final weights. Weight losses of cherry fruit were expressed as percentage (\%).

Fruit firmness: Fifteen cherries from each replicate were used for firmness evaluation. Firmness was measured using a texture analyzer machine (Lloyd Instruments LF Plus) with a $50 \mathrm{~N}$ load cell ( $5 \mathrm{~mm}$ cylindrical probe). The results were expressed as Newton (N).

Colour determinations: Fruit stem and skin colour (20 stem and fruit for each replicate) were determined using colorimeter (Minolta CR-300). Values of $L^{*}, a^{*}$ and $b^{*}$, which used to define a three-dimensional colour space, were measured. The $a^{*}$ and $b^{*}$ values were used to calculate Chroma $\left[\mathrm{C}^{*}=\left(\mathrm{a}^{* 2}+\mathrm{b}^{* 2}\right)^{1 / 2}\right]$ and Hue angle $\left(\mathrm{h}^{\circ}=\tan \right.$ $\left.{ }^{1} b^{*} / a^{*}\right)$ values.

Soluble solids content (SSC) and titratable acidity (TA): Fruit juice was extracted, and the SSC (\%) was determined by using a digital refractometer (Atago-PAL1). For TA, fruit juice $(10 \mathrm{~mL})$ was titrated with $0.1 \mathrm{~N}$ sodium hydroxide up to $\mathrm{pH} 8.1$, and results were expressed as percentage.

Respiration rate: Respiration rate of fruit was measured by using gas chromatography. Fruit (140$150 \mathrm{~g}$ ) were placed in a $1 \mathrm{~L}$ glass jar, hermetically sealed, for $1 \mathrm{~h}$ in room temperature. Gas sample was taken by a gas-tight syringe, and injected into a gas chromatography (Agilent 6890N) equipped with a thermal conductivity detector. Results were expressed as $\mathrm{mLCO}_{2} \mathrm{~kg}^{-1} \mathrm{~h}^{-1}$.

Total phenolic and anthocyanin content: Cherry fruit were extracted for these analyses according to procedure used by Ağlar et al. (2017). Extracted supernatants were stored at $-20^{\circ} \mathrm{C}$ until the day of analysis. Total phenolic content and total anthocyanin content were determined by using spectrophotometric method according to Singleton and Rossi (1965) and Giusti et al. (1999), respectively. The results were expressed as $\mathrm{mg}$ gallic acid equivalent (GAE) on FW basis (mg GAE $100 \mathrm{~g}^{-1}$ ) for total phenolic content and $\mathrm{mg}$ in $\mathrm{kg}$ cyanidin 3-glucoside (cy-3-glu) on FW basis (mg kg-1 cy-3-glu) for total anthocyanin content.

Stem chlorophyll content: Chlorophyll extraction and stem chlorophyll analysis were performed to procedure described by Göksel (2011). The results

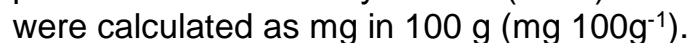

External appearance and taste: External appearance and taste of fruit were determined with hedonic test. Two scales from 1 to 9 ( $\leq 1-4$ : poor, 9 : excellent) and from 1 to 5 (1: very poor, 5 : excellent) were used for external appearance and taste evaluation, respectively (Erbaş et al., 2015).

\subsection{Statistical analysis}

The study was conducted to completely factorial randomized design with 3 replicate (each box 
Table 1. Anova for dependent variables for treatments, storage period and their interactions for sweet cherry

\begin{tabular}{|c|c|c|c|}
\hline Variables & Storage periods (SP) & Treatments $(T)$ & $\mathrm{SP} \times \mathrm{T}$ \\
\hline Weight loss & ** & * & $\mathrm{ns}$ \\
\hline Respiration rate & NS & NS & NS \\
\hline Fruit firmness & ** & * & NS \\
\hline External appearance & ** & ** & ** \\
\hline Taste & ** & ** & NS \\
\hline Fruit skin colour $L^{*}$ & ** & NS & NS \\
\hline Fruit skin colour $\mathrm{C}^{*}$ & ** & NS & NS \\
\hline Fruit skin colour $\mathrm{h}^{\circ}$ & ** & NS & NS \\
\hline Stem colour $\mathrm{L}^{*}$ & ** & * & NS \\
\hline Stem colour $\mathrm{C}^{*}$ & ** & * & NS \\
\hline Stem colour $\mathrm{h}$ & ** & NS & NS \\
\hline
\end{tabular}

${ }^{*}$ NS represents non-significance at $p<0.05 ;{ }^{* *}$ Represents significance at the 0.01 level; ${ }^{*}$ Represents significance at the 0.05 level.
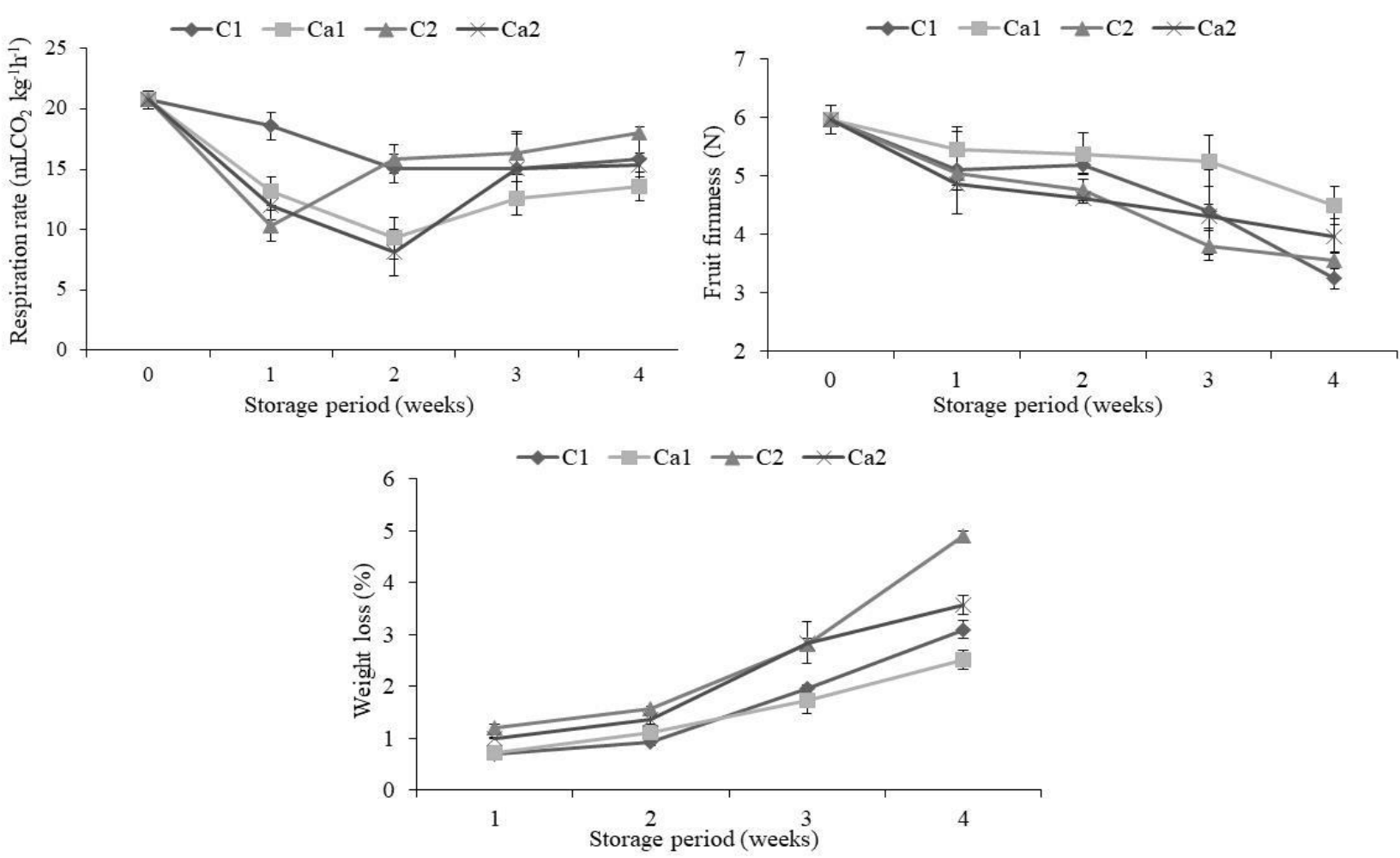

Figure 1. Respiration rate, fruit firmness and weight loss of 0900 Ziraat sweet cherry fruit during cold storage (Data are mean \pm S.E. C1: Control group in plastic boxes with lid; Ca1: Ca group in plastic boxes with lid, C2: Control group in plastic boxes without lid; $\mathrm{Ca2}$ : Ca group in plastic boxes without lid).

containing $750 \mathrm{~g}$ fruit was regarded as a replication). The data was analyzed using Minitab 18 statistics software. The differences among means were compared with Tukey's range test (5\%).

\section{Results and Discussion}

\subsection{Respiration rate, fruit firmness and weight loss}

The respiration rate of fruit at harvest was $20.74 \mathrm{mLCO}_{2} \mathrm{~kg}^{-1} \mathrm{~h}^{-1}$. When fruit were placed to cold storage, respiration rate decreased sharply in all treatments but this decrease was higher in $\mathrm{Ca}$ treated fruit compared to control. The lowest respiration rates were $13.53 \mathrm{~mL} \mathrm{CO}_{2} \mathrm{~kg}^{-1} \mathrm{~h}^{-1}$ (Ca1) and $15.37 \mathrm{~mL} \mathrm{CO}_{2} \mathrm{~kg}^{-1} \mathrm{~h}^{-1}(\mathrm{Ca} 2)$ at the end of the storage. Although there was no statistically difference between treatments and control group (Table 1), Ca dip treatments reduced, relatively, respiration rate of sweet cherry fruit (Figure 1). The decrease in the respiration rate of fruit might be due to the delaying of senescence processes. $\mathrm{Ca}$ treatments resulting in decreased respiration rate and delayed maturity have been reported in previous studies carried out on climacteric or nonclimacteric fruit (Lara et al., 2004; Shafiee et al., 2010; Wang et al., 2014). Moreover, in the present study, the reduced oxygen and increased carbon dioxide by using the boxes with lid contributed to reduce respiration rate in sweet cherry fruit. Accordingly, as seen in Figure 1, the lowest respiration rate was obtained from combination of boxes with lid and $\mathrm{Ca}$ treatment at the end of the storage.

Fruit firmness of sweet cherries is one of the main quality attributes for consumer acceptance. $\mathrm{Ca}$ treatments significantly affected the fruit 
firmness of cherry fruit (Table 1). Fruit firmness, which was $5.96 \mathrm{~N}$ at harvest, decreased with prolonging storage in all treatments (Figure 1). During cold storage, the delay in softening has been reported by Manganaris et al., 2007 and Naser et al., 2018 in $\mathrm{Ca}$ treated peach and persimmon, respectively. Ca treated fruit had greater fruit firmness compared to control groups. Especially, fruit in $\mathrm{Ca} 1$ treatment more firm than those of $\mathrm{Ca}$, and the softest fruit were observed in control groups at the end of storage (Figure 1). As known, increased weight loss can result in reduced fruit firmness (Mitcham et al., 1998). In the present study, a negative relationship between weight loss and fruit firmness was observed. The results indicated that $\mathrm{Ca}$ applications retarded fruit softening, especially in plastic boxes with lid depending on decreased weight loss (Figure 1). Likewise, Wang et al. (2014) indicated that pre or postharvest $\mathrm{Ca}$ applications generally contribute fruit firmness by increasing turgor pressure of cell and decreasing water loss of tissue. On the other hand, Serrano et al. (2005) reported that the high oxygen concentration in storage increased the softening of tissues in sweet cherry fruit.

Weight loss is one of the major problems which responsible for quality loss for stored cherries, and is related to loss of water vapor (Mitcham et al., 1998). In the present study, weight loss of sweet cherry fruit increased as storage time proceeds in all treatments. At the end of the storage, C2 treatment had the highest weight loss $(4.89 \%)$ followed by $\mathrm{Ca} 2(3.57 \%), \mathrm{C} 1$ (3.10\%) and $\mathrm{Ca} 1$ $(2.52 \%)$ treatments. Ca1 treatment showed the lowest weight loss, together with the lowest firmness loss (Figure 1). Garcia et al. (1996) reported the same effect on weight loss for strawberries, which were immersed in Ca solution. Weight or water loss is generally linked to moisture evaporation through the fruit skin and respiration rate of fruit. It is thought that lower weight losses in $\mathrm{C} 1$ and $\mathrm{Ca} 1$ treatments can be attributed to higher $\mathrm{RH}$ in these boxes. Similarly, Serrano et al. (2005) reported that the high $\mathrm{RH}$ inside the boxes might be responsible for the retarded softening and water loss.

\subsection{Soluble solids content (SSC) and titratable acidity (TA)}

Changes in the SSC and TA of cherry fruit are shown in Table 2. Regardless of treatments, the SSC of cherries showed fluctuation during storage but decreased compared to initial value $(12.97 \%)$ at the end of the storage. Similar fluctuation in the SSC of sweet cherries throughout storage was declared by (Giacalone and Chiabrando, 2013; Wang et al., 2014). At the $3^{\text {th }}$ weeks of storage, the SSC of cherries reached the maximum levels (except for Ca1 treatment) and then slightly decreased in all treatments. It is considered that these results are related to the weight loss and respiration rate of cherries. This thought was supported by $\mathrm{Ca} 1$ treatment, which had the lowest weight loss (Figure 1). Similarly, Güneyli et al. (2018) reported that the SSC was influenced by the weight loss of fruit causing, usually, an increase in the SSC of sweet cherries. On the other hand, Kluge et al. (1996) expressed that sugar decreases during storage might be caused by the use of sugars in respiration.

The TA of cherries decrease overtime compared to initial value $(0.89 \%)$ varying between $0.71 \%$ (C1 and $\mathrm{C} 2$ ) and $0.79 \%$ (Ca1) at the end of the storage. The Ca1 $(0.83 \%)$ was the best treatment for maintaining the acidity of cherries followed by $\mathrm{Ca} 2$ $(0.80 \%), \mathrm{C} 1(0.80 \%)$ and C2 $(0.77 \%)$. Accordance with the present study, the TA losses were delayed by $\mathrm{Ca}$ treatments in previous research of Wang et al. (2004). Maintaining TA with Ca1 treatment can be explained by its suppressing effect on fruit metabolism, especially respiration rate (Figure 1). It has been reported that acids are a major component of respiration process (Kays and Paull, 2004), and the use of organic acids as substrates in respiration and enzymatic reactions reduce acid content in fruit (Certel et al., 2004).

\subsection{Fruit skin and stem colour}

Fruit (bright red) and stem (green) colour is the most important quality attributes for consumers. The change in skin and stem $L^{*}$ (lightness) values of fruit showed similar trend in all treatments. As seen in Figure $2, L^{*}$ values of stem and fruit decreased, in general, during cold storage but $\mathrm{Ca} 1$ treatment was most effective on fruit and stem lightness. Moreover, Ca1 treatment had higher hue angle $\left(\mathrm{h}^{\circ}\right)$ and chroma values (both skin and stem) than the other treatment (data not shown). Hue angle values decrease with increasing maturity, and the vividness of the colour become apparent with the increase of the $C^{*}$ values in sweet cherries (Mozetic et al., 2004). In the present study, $L^{*}, C^{*}$ and $h^{\circ}$ values decreased gradually, and $\mathrm{Ca} 1$ treatment delayed their reductions slightly. Considering the stem and skin colour values, it could be said that Ca1 treatment delayed the colour deterioration of sweet cherries. Wang and Long (2015) indicated that delaying colour change or darkening by $\mathrm{Ca}$ treatments may be associated with its prevention of senescence in sweet cherries.

\subsection{Sensory analysis}

Sensory tests of cherries are presented in Figure 3. The taste and external appearance scores of sweet cherry fruit reduced with prolonging storage time. Boxes and $\mathrm{Ca}$ treatments affected sensory quality of sweet cherries. Cherries in Ca1 treatment had the best sensory quality scores compared to other treatments. The quality loss of cherries started to increase especially after $2^{\text {th }}$ weeks of storage. At the 4 weeks of storage, the higher external appearance score (5.00) was obtained from Ca1 
Table 2. Soluble solids content (SSC) and titratable acidity (TA) of 0900 Ziraat sweet cherry fruit during cold storage

\begin{tabular}{|c|c|c|c|c|c|c|c|}
\hline \multirow{2}{*}{ Parameters } & \multirow{2}{*}{$\begin{array}{l}\text { Treatments } \\
(\mathrm{T})\end{array}$} & \multicolumn{5}{|c|}{ Storage periods (weeks) } & \multirow{2}{*}{ - Means } \\
\hline & & Harvest & 1 & 2 & 3 & 4 & \\
\hline \multirow{5}{*}{ SSC (\%) } & $\mathrm{C} 1$ & \multirow{4}{*}{12.97} & 13.00 & 12.97 & 13.17 & 12.90 & $13.00 \mathrm{a}$ \\
\hline & Ca1 & & 11.07 & 11.83 & 12.37 & 12.83 & $12.21 \mathrm{~b}$ \\
\hline & $\mathrm{C} 2$ & & 12.93 & 12.93 & 13.10 & 12.80 & $12.95 \mathrm{a}$ \\
\hline & $\mathrm{Ca} 2$ & & 11.70 & 11.60 & 13.20 & 12.77 & $12.45 \mathrm{ab}$ \\
\hline & Means & $12.97 \mathrm{ab}$ & $12.17 \mathrm{c}$ & $12.33 \mathrm{bc}$ & $12.96 \mathrm{a}$ & $12.83 a b$ & \\
\hline \multirow{5}{*}{ TA (\%) } & $\mathrm{C} 1$ & \multirow{4}{*}{0.89} & 0.81 & 0.83 & 0.77 & 0.71 & $0.80 \mathrm{ab}$ \\
\hline & Ca1 & & 0.82 & 0.81 & 0.81 & 0.79 & $0.83 a$ \\
\hline & $\mathrm{C} 2$ & & 0.79 & 0.72 & 0.73 & 0.71 & $0.77 \mathrm{~b}$ \\
\hline & $\mathrm{Ca} 2$ & & 0.78 & 0.76 & 0.82 & 0.76 & $0.80 a b$ \\
\hline & Means & $0.89 a$ & $0.80 \mathrm{ab}$ & $0.78 \mathrm{ab}$ & $0.78 a b$ & $0.74 \mathrm{~b}$ & \\
\hline \multicolumn{2}{|l|}{$P$ values } & \multicolumn{2}{|c|}{ Storage periods (SP) } & Treatments & & $\mathrm{SP} \times \mathrm{T}$ & \\
\hline \multicolumn{2}{|l|}{ SSC } & \multicolumn{2}{|l|}{ * } & ** & & NS & \\
\hline \multicolumn{2}{|l|}{ TA } & \multicolumn{2}{|l|}{ ** } & ** & & NS & \\
\hline
\end{tabular}

Means followed by the same letter in the same column are not statistically significant $(P<0.05)$. NS represents non-significance at $p<0.05$; ${ }^{* *}$ Represents significance at the 0.01 level; ${ }^{*}$ Represents significance at the 0.05 level. C1: Control group in plastic boxes with lid; Ca1: Ca group in plastic boxes with lid, C2: Control group in plastic boxes without lid; Ca2: Ca group in plastic boxes without lid.
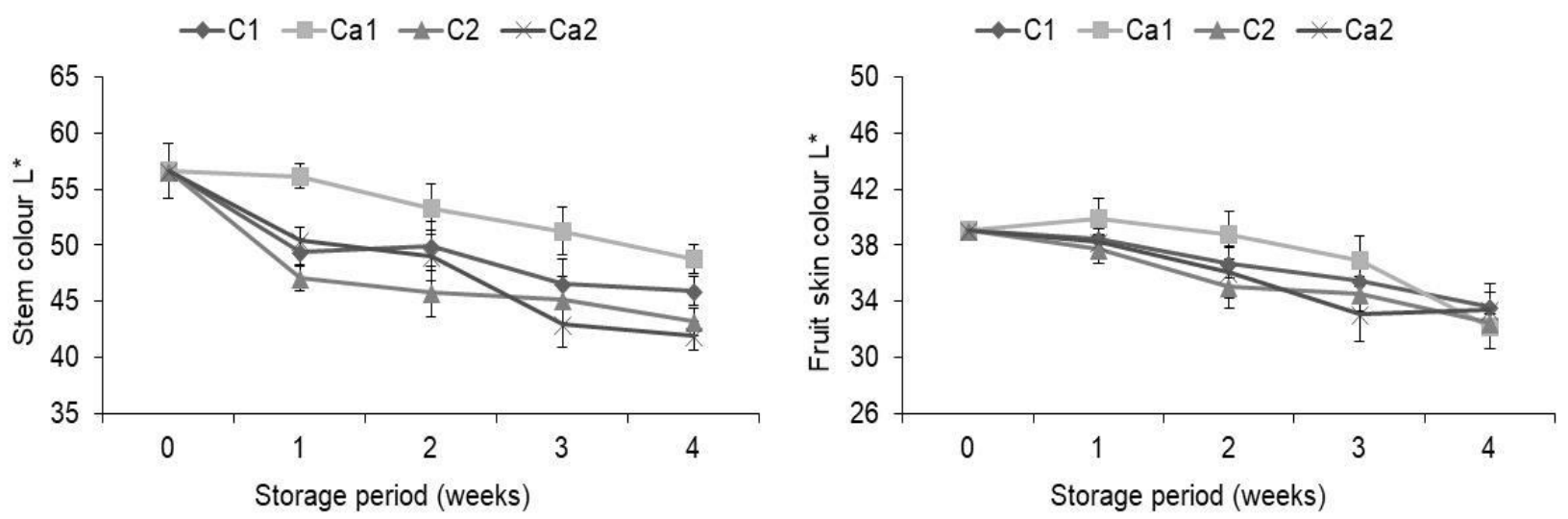

Figure 2. Fruit skin and stem colour $L^{*}$ values of 0900 Ziraat sweet cherry fruit during cold storage

(Data are mean \pm S.E. C1: Control group in plastic boxes with lid; Ca1: Ca group in plastic boxes with lid, C2: Control group in plastic boxes without lid; $\mathrm{Ca2}$ : Ca group in plastic boxes without lid).
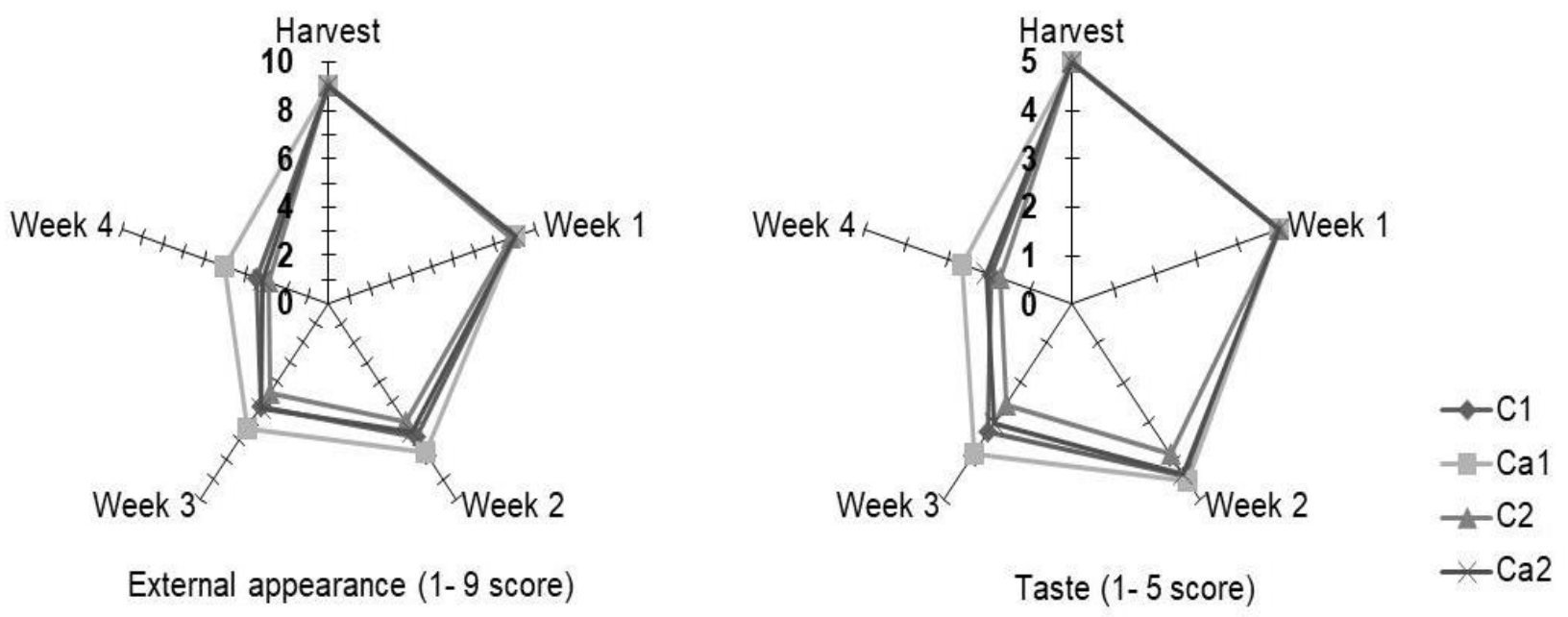

Figure 3. External appearance and taste of 0900 Ziraat sweet cherry fruit during cold storage

(C1: Control group in plastic boxes with lid; Ca1: Ca group in plastic boxes with lid, C2: Control group in plastic boxes without lid; Ca2: Ca group in plastic boxes without lid). 
Table 2. Total phenolic content, anthocyanin content and stem total chlorophyll content of 0900 Ziraat sweet cherry fruit during cold storage

\begin{tabular}{|c|c|c|c|c|c|}
\hline \multirow{2}{*}{ Parameters } & \multirow{2}{*}{ Treatments } & \multicolumn{3}{|c|}{ Storage period (weeks) } & \multirow{2}{*}{ Means } \\
\hline & & Harvest & 2 & 4 & \\
\hline \multirow{5}{*}{$\begin{array}{c}\text { Total phenolic } \\
\text { content } \\
\left(\mathrm{mg} 100 \mathrm{~g}^{-1}\right)\end{array}$} & $\mathrm{C} 1$ & \multirow{4}{*}{32.85} & 41.11 & 49.47 & $41.14^{\mathrm{ns}}$ \\
\hline & $\mathrm{Ca} 1$ & & 40.66 & 44.97 & 39.49 \\
\hline & $\mathrm{C} 2$ & & 46.29 & 60.52 & 46.55 \\
\hline & $\mathrm{Ca} 2$ & & 43.45 & 52.54 & 42.95 \\
\hline & Means & $32.85 \mathrm{c}$ & $42.88 \mathrm{~b}$ & $50.21 \mathrm{a}$ & \\
\hline \multirow{5}{*}{$\begin{array}{c}\text { Total anthociyanin } \\
\text { content } \\
\left(\mathrm{mg} \mathrm{kg}^{-1}\right)\end{array}$} & C1 & \multirow{4}{*}{13.02} & 17.22 & 18.17 & $16.14^{\mathrm{ns}}$ \\
\hline & $\mathrm{Ca} 1$ & & 16.72 & 19.42 & 16.39 \\
\hline & $\mathrm{C} 2$ & & 19.80 & 17.02 & 16.61 \\
\hline & $\mathrm{Ca} 2$ & & 19.81 & 19.52 & 17.45 \\
\hline & Means & $13.02 \mathrm{~b}$ & $18.39 \mathrm{a}$ & $18.53 \mathrm{a}$ & \\
\hline \multirow{9}{*}{ 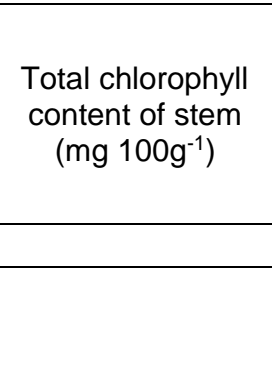 } & $\mathrm{C} 1$ & \multirow{4}{*}{5.82} & 3.85 & 2.41 & $4.02 \mathrm{ab}$ \\
\hline & Ca1 & & 4.70 & 2.71 & $4.41 \mathrm{a}$ \\
\hline & $\mathrm{C} 2$ & & 3.45 & 1.72 & $3.66 \mathrm{~b}$ \\
\hline & $\mathrm{Ca} 2$ & & 3.72 & 2.64 & $4.06 \mathrm{ab}$ \\
\hline & Means & $6.18 \mathrm{a}$ & $3.93 \mathrm{~b}$ & $2.37 \mathrm{c}$ & \\
\hline & $P$ values & & Storage period (SP) & Treatments $(\mathrm{T})$ & $\mathrm{SP} \times \mathrm{T}$ \\
\hline & \multicolumn{2}{|c|}{ Total phenolic content } & ** & NS & NS \\
\hline & \multirow{2}{*}{\multicolumn{2}{|c|}{$\begin{array}{l}\text { Total anthociyanin content } \\
\text { Total chlorophyll content of stem }\end{array}$}} & ** & NS & NS \\
\hline & & & ** & ** & NS \\
\hline
\end{tabular}

Means followed by the same letter in the same column are not statistically significant $(P<0.05)$. NS represents non-significance at $\mathrm{p}<$ $0.05 ;{ }^{* *}$ Represents significance at the 0.01 level; ${ }^{*}$ Represents significance at the 0.05 level. C1: Control group in plastic boxes with lid; Ca1: Ca group in plastic boxes with lid, C2: Control group in plastic boxes without lid; Ca2: Ca group in plastic boxes without lid.

treatment, while the lowest score (2.89) was determined in $\mathrm{C} 2$ treatment. Similar trend was also observed in taste evaluation. The best (2.67) and the worst score (1.72) was determined in Ca1 and C2 treatments, respectively at the end of the storage. Cherries with marketable scores $(\geq 5)$ were only determined from Ca1 treatments (5.00) at the $4^{\text {th }}$ weeks of storage. C2 treatments (4.61) lost their marketable quality at the $3^{\text {th }}$ weeks of storage. C1 (5.28) and $\mathrm{Ca} 2$ (5.33) treatments preserved the marketable quality at the $3^{\text {th }}$ weeks of storage. It was reported that Ca treatment was proved to delay tissue weakening, increase membrane integrity and reduce decay rate in fruit (Manganaris et al., 2005). At the same time, Wang et al. (2014) stated that $\mathrm{Ca}$ is effective in maintaining the fruit quality and reducing the disorders that may occur during cold storage. Similar results were also determined in present study.

\subsection{Total phenolics, anthocyanin content and stem total chlorophyll content}

Phenolic compounds have important effects on the fruit quality such as colour, taste and aroma (Göksel, 2011). During cold storage, total phenolic content of cherry fruit increased in all treatments. The highest total phenolic content (60.52 mg GAE $100 \mathrm{~g}^{-1}$ ) was determined from C2 treatment, whereas the lowest value (44.97 mg GAE $100 \mathrm{~g}^{-1}$ ) was measured in Ca1 treatment at the end of the storage. The $\mathrm{Ca}$ treatments affected the total phenolic content of cherry fruit depending on the packaging. The fruit in plastic boxes with lid had the lowest phenolic content, while fruit placed in open plastic boxes gave the highest values (Table 3 ). Higher phenolic content values can be attributed to higher water loss and increased stress conditions caused by open plastic boxes. As a stress factor, the cold air circulation in the atmosphere surrounding fruit can affect them in open boxes compared to closed ones with lid. It is known that the accumulation of phenolic compounds in fruit increases under stress conditions (Li et al., 2018), and fruit stored in plastic boxes with lid might have been exposed to less stress in the present study.

Anthocyanins (responsible to red colour of fruit and vegetables) are important phenolic compounds in cherry fruit (Aghdama et al., 2013). In the present study, according to general means, the anthocyanin content of fruit increased during storage (Table 3 ), accordance with several authors who reported similar increase (Bernalte et al., 2003; Ağlar et al., 2017). Total anthocyanin content of cherry fruit at harvest was $13.02 \mathrm{mg} \mathrm{kg}^{-1}$. Total anthocyanin content of fruit in Ca1 was lower $\left(16.72 \mathrm{mg} \mathrm{kg}^{-1}\right)$ than other treatments on the $2^{\text {th }}$ week of storage. Anthocyanin contents of cherry fruit in C1 and Ca1 treatments increased slightly up to 2 weeks, on the contrary of other two treatments. Treatments did not affect total anthocyanin content of cherry fruit $(\mathrm{P}<0.05)$. However, fruit stored in closed boxes with lid had lower (C1: $16.14 \mathrm{mg} \mathrm{kg}^{-1}$; Ca1: $16.39 \mathrm{mg} \mathrm{kg}^{-}$ $\left.{ }^{1}\right)$ anthocyanin contents compared to those without lid (C2: $16.61 \mathrm{mg} \mathrm{kg}^{-1}$; Ca2: $17.45 \mathrm{mg} \mathrm{kg}^{-1}$ ) (Table $3)$. This can be explained by the proportional increase of anthocyanin contents in open boxes 
depending on higher water loss and quick ripening in fruit. Similarly, Giacalone and Chiabrando (2013) stated that modified atmosphere packaging (MAP) treatments delayed anthocyanin biosynthesis of sweet cherry fruit.

Stem colour, one of the most important indicators for determining the freshness of cherry fruit, changes during storage because of the chlorophyll breakdown. Göksel (2011) declared rapid declines in total chlorophyll content of stems throughout cold the storage, similar to the findings of the present study (Table 3). Compared to initial value $\left(5.82 \mathrm{mg}^{100 \mathrm{~g}^{-1}}\right)$ the lowest decrease in chlorophyll content was obtained from $\mathrm{Ca} 1$ and $\mathrm{Ca} 2$ treatments. These results showed that $\mathrm{Ca}$ treatments had a positive effect on total chlorophyll content of stems. Sweet cherry fruit stored in boxes with lid also had the low chlorophyll losses compared to boxes without lid. This result can be attributed to higher oxidation and senescence processes in fruit stems stored in open boxes.

\section{Conclusions}

In conclusion, it is found that postharvest $\mathrm{Ca}$ treatments could reduce respiration rate and maintain fruit firmness of sweet cherry fruit during cold storage. Moreover, Ca treatments had positive effects on maintaining sweet cherry skin colour, stem colour and sensory quality. But these positive effects were more noticeable when fruit were stored in boxes with lid compared to open boxes. According to sensory scores, the fruit in Ca1 treatment, which had the best results for storage life and quality, could be stored with good quality for 34 weeks. This treatment was followed by $\mathrm{C} 1$ (3 weeks), Ca2 and C2 (2 weeks) applications.

\section{References}

Aghdama, M.S., Dokhaniehb, A.Y., Hassanpourc, H., \& Fard, J.R. (2013). Enhancement of antioxidant capacity of cornelian cherry (Cornus mas) fruit by postharvest calcium treatment. Scientia Horticulturae, 161:160-164

Ağlar, E., Öztürk, B., Güler, S. K., Karakaya, O., Uzun, S., \& Saraçoğlu, O. (2017). Effect of modified atmosphere packaging and 'Parka' treatments on fruit quality characteristics of sweet cherry fruits (Prunus avium L. 0900 Ziraat) during cold storage and shelf life. Scientia Horticulturae, 222:162-168.

Akhtar, I., \& Rab, A. (2014). Influence of calcium sources and concentration on the storage performance of strawberry fruit. Journal of Agricultural Science and Technology B, 4:661-673.

Bernalte, M.J., Sabio, E., Hernandez, M.T. \& Gervasini, C. (2003). Influence of storage delay on quality of Van sweet cherry. Postharvest Biology and Technology, 28:303-312.

Certel, M., Uslu, M.K., \& Ozdemir, F. (2004). Effects of sodium caseinate and milk protein concentrate-based edible coatings on the postharvest quality of Bing cherries. Journal of the Science of Food and Agriculture, 84:1229-1234.
Dong, Y., Zhi, H., \& Wang, Y. (2019). Cooperative effects of pre-harvest calcium and gibberellic acid on tissue calcium content, quality attributes, and in relation to postharvest disorders of late-maturing sweet cherry. Scientia Horticulturae, 246:123-128.

Erbaş, D., Onursal, C.E., \& Koyuncu, M.A. (2015). Effect of postharvest salicylic acid treatments on cold storage of apricot cv. Aprikoz. Fruit Science, 2:50-57.

García, J.M., Herrera, S., \& Morilla, A. (1996). Effects of postharvest dips in calcium chloride on strawberry. Journal of Agricultural and Food Chemistry, 44:30-33.

Giacalone, G., \& Chiabrando, V. (2013). Modified atmosphere packaging of sweet cherries with biodegradable films. International Food Research Journal, 20:1263-1268.

Giusti, M.M., Rodriguez-Saona, L.E., \& Wrolstad, R.E. (1999). Spectral characteristics, molar absorptivity and color of pelargonidin derivatives. Journal of Agriculture Food Chemistry, 47:4631-7.

Göksel, Z. (2011). Effects of some pre-treatments on storability of sweet cherries. PhD Thesis, Ege University, İzmir (In Turkish).

Göksel, Z., \& Aksoy, U. (2014). Physico-chemical characteristics of some table sweet cherry varieties. Turkish Journal of Agricultural and Natural Sciences, 1:1856-1862.

Göksel, Z., Akçay, M.E., \& Özdemir, Y. (2013). Fruit antioxidant activity, total phenolic content and sugar composition of some sweet cherry (Prunus avium L.) cultivars. Journal of Agriculture Faculty of Ege University, Special Issue 2:429-432.

Güneyli, A., Koyuncu, M.A., Onursal, C. E., Erbaş, D., Çetinbaş, M., Butar, S., \& Koyuncu, F. (2018). Effects of pre-harvest retain treatments with MAP on cold storage quality of sweet cherry cv. '0900 Ziraat'. Scientific Papers Series B Horticulture Vol. LXII:153158.

Hernández-Muñoz, P., Almenar, E., Ocio, M. J., \& Gavara, R. (2006). Effect of calcium dips and chitosan coatings on postharvest life of strawberries (Fragaria $x$ ananassa). Postharvest Biology and Technology, 39:247-253.

Hosein-Beigi, M., Zarei, A., Rostaminia, M., \& ErfaniMoghadam, J. (2019). Positive effects of foliar application of $\mathrm{Ca}, \mathrm{B}$ and $\mathrm{GA} 3$ on the qualitative and quantitative traits of pomegranate (Punica granatum L.) cv. 'Malase-Torshe-Saveh'. Scientia Horticulturae, 254:40-47.

Kays, S.J., \& Paull, R.E. (2004). Postharvest Biology. Exon Press, p. 568, United States.

Kluge, R.A., Bilhalva, A.B. \& Cantillano, R.F.F. (1996). Cold storage of Reubennel plums (Prunus salicina Lindl.): Effects of ripening stage and polyethylene packing. Scientia Agricola, 53:365-369.

Lara, I., Garcıa, P., \& Vendrell, M. (2004). Modifications in cell wall composition after cold storage of calciumtreated strawberry (Fragaria $\times$ ananassa Duch.) fruit. Postharvest Biology and Technology, 34:331-339.

Le Nguyen, L.P., Visy, A., Baranyai, L., Friedrich, L., \& Mahajan, P.V. (2020). Application of hue spectra fingerprinting during cold storage and shelf-life of packaged sweet cherry. Journal of Food Measurement and Characterization, 14:2689-2702.

Li, X., Li, M., Wang, L., Wang, J., Jin, P., \& Zheng, Y. (2018). Methyl jasmonate primes defense responses against wounding stress and enhances phenolic accumulation in fresh-cut pitaya fruit. Postharvest Biology and Technology, 145:101-107. 
Manganaris, G.A., Vasilakakis, M., Diamantidis, G., \& Mignani, I. (2005). Effect of calcium additives on physicochemical aspects of cell wall pectin and sensory attributes of canned peach (Prunus persica L. Batsch cv. Andross). Journal of the Science of Food and Agriculture, 85:1773-1778.

Manganaris, G.A., Vasilakakis, M., Diamantidis, G., \& Mignani, I.J.F.C. (2007). The effect of postharvest calcium application on tissue calcium concentration, quality attributes incidence of flesh browning and cell wall physicochemical aspects of peach fruits. Food Chemistry, 100(4):1385-1392.

Martínez-Romero, D., Alburquerque, N., Valverde, J.M., Guillén, F., Castillo, S., Valero, D., \& Serrano, M. (2006). Postharvest sweet cherry quality and safety maintenance by Aloe vera treatment: a new edible coating. Postharvest Biology and Technology, 39:93100.

Miranda, S., Vilches, P., Suazo, M., Pavez, L., García, K., Méndez, M.A., Gonzales, M., Meisel, L.A., Defilippi, B.G., \& Pozo, T. (2020). Melatonin triggers metabolic and gene expression changes leading to improved quality traits of two sweet cherry cultivars during cold storage. Food Chemistry, 319:126360.

Michailidis, M., Karagiannis, E., Tanou, G., Karamanoli, K., Lazaridou, A., Matsi, T., \& Molassiotis, A. (2017). Metabolomic and physico-chemical approach unravel dynamic regulation of calcium in sweet cherry fruit physiology. Plant Physiology and Biochemistry, 116:68-79.

Mitcham, E.J., Clayton, M., \& Biasi, W.V. (1998). Comparison of devices for measuring cherry fruit firmness. HortScience, 33:723-727.

Monsalve-Gonález, A., Barbosa-Cánovas, G.V., \& Cavalieri, R.P. (1993). Mass transfer and textural changes during processing of apples by combined methods. Journal of Food Science, 58:1118-1124.

Mozetič, B., Trebše, P., Simičič, M., \& Hribar, J., (2004). Changes of anthocyanins and hydroxycinnamic acids affecting the skin colour during maturation of sweet cherries (Prunus avium L.). LWT-Food Science and Technology, 37:123-128.

Naser, F., Rabiei, V., Razavi, F., \& Khademi, O. (2018). Effect of calcium lactate in combination with hot water treatment on the nutritional quality of persimmon fruit during cold storage. Scientia Horticulturae, 233:114123.

Öztürk, B., Ağlar, E., Karakaya, O., Saracoğlu, O., \& Gün, S. (2019). Effects of preharvest $\mathrm{GA} 3, \mathrm{CaCl} 2$ and modified atmosphere packaging treatments on specific phenolic compounds of sweet cherry. Turkish Journal of Food and Agriculture Sciences, 1:44-56.

Serrano, M., Martinez-Romero, D., Castillo, S., Guillén, F., \& Valero, D. (2005). The use of natural antifungal compounds improves the beneficial effect of MAP in sweet cherry storage. Innovative Food Science \& Emerging Technologies, 6:115-123.

Shafiee, M., Taghavi, T. S., \& Babalar, M. (2010). Addition of salicylic acid to nutrient solution combined with postharvest treatments (hot water, salicylic acid, and calcium dipping) improved postharvest fruit quality of strawberry. Scientia Horticulturae, 124:40-45.

Singleton, V.L., \& Rossi, J.A. (1965). Colorimetry of total phenolics with phosphomolybdic-phosphotungstic acid reagents. American Journal of Enology and Viticulture, 16:144-158

Wang, Y., \& Long, L.E. (2015). Physiological and biochemical changes relating to postharvest splitting of sweet cherries affected by calcium application in hydrocooling water. Food Chemistry, 181:241-247.

Wang, Y., Xie, X., \& Long, L.E. (2014). The effect of postharvest calcium application in hydro-cooling water on tissue calcium content, biochemical changes, and quality attributes of sweet cherry fruit. Food Chemistry, 160:22-30.

Wójcik, P., \& Wawrzyńczak, P. (2014). Effect of preharvest sprays of calcium on cracking and 'Schattenmorelle' sour cherry fruit quality harvested mechanically. Journal of Plant Nutrition, 37:14871497. 